\title{
KAMPANYE PENGHENTIAN KLITORIDEKTOMI DAN PERAN STRATEGIS HIMPSI
}

\author{
Reza Indragiri Amriel \\ Jurusan Psikologi, Fakultas Psikologi, Bina Nusantara University \\ Jln. Kemanggisan Ilir III No 45, Kemanggisan, Palmerah, Jakarta Barat 11480 \\ r_amriel@binus.edu
}

\begin{abstract}
If the word "mutilation" entered in internet search engine, pages appear will be about "female genital mutilation" (FGM). Association about mutilation and female genital mutilation gives a negative connotation to "mutilation" term, that is such harmful practical towards women. This connotation affects Indonesia, as according to UNICEF (2005), Indonesia is one of many countries practicing FGM. Besides considering psichological concequences that will harm women, circumcision phenomenon in women unlocks sensitivity in self-judging towards Islam community as the major community in Indonesia. This paper bring up description about FGM and its strategic consideration about psychologic part taken care by Indonesian Psychology Association (HIMPSI) as its future agenda.
\end{abstract}

Keywords: female genital mutilation (FGM), women rights, psychological effect, HIMPSI, API

\begin{abstract}
ABSTRAK
Apabila kata "mutilation" (mutilasi) dimasukkan ke mesin pencari maya, laman-laman yang muncul sangat didominasi oleh "female genital mutilation" (FGM, khitan pada perempuan). Asosiasi antara mutilation dan female genital mutilation memberikan garis bawah bahwa istilah "mutilation" berkonotasi negatif, yakni praktik semacam ini merupakan bentuk kekerasan bahkan penindasan terhadap kaum perempuan. Konotasi sedemikian rupa secara langsung mengena ke Indonesia, karena menurut UNICEF (2005), Indonesia adalah salah satu negara yang banyak mempraktikkan mutilasi genitalia perempuan (MGP). Di samping memerhatikan konsekuensi-konsekuensi psikologis yang merugikan kaum perempuan, fenomena khitan pada perempuan membuka ruang sensitif bagi munculnya penghakiman terhadap komunitas Islam yang merupakan komunitas mayoritas di Indonesia. Makalah ini memuat uraian mengenai MGP serta pertimbangan-pertimbangan strategis tentang peran psikologi yang patut dikelola oleh Himpunan Psikologi Indonesia (HIMPSI) sebagai agenda kerjanya ke depan.
\end{abstract}

Kata kunci: mutilasi genitalia perempuan (MGP), hak azasi perempuan, efek psikologi, HIMPSI, API 


\section{PENDAHULUAN}

Apabila kata "mutilation" (mutilasi) dimasukkan ke mesin pencari maya, laman-laman yang muncul sangat didominasi oleh "female genital mutilation" (FGM). Penggunaan istilah "mutilasi" yang diidentikkan dengan praktik khitan pada perempuan, diintroduksi oleh Organisasi Kesehatan Dunia (WHO) sejak tahun 1991. Sejak itu, di dalam dokumen-dokumen PBB, "mutilation” dipakai sebagai istilah pengganti "circiumcision" (khitan). Tentu, bukan sebatas penggantian sebutan belaka; penggunaan istilah "mutilasi” berkonotasi negatif, karena mengandung penekanan bahwa mutilasi genitalia perempuan (MGP) merupakan bentuk kekerasan bahkan penindasan terhadap kaum perempuan.

Di dalam definisi resminya (dipublikasikan tahun 1995), WHO menyebutkan bahwa MGP mencakup segala bentuk prosedur yang menyertakan pembuangan sebagian maupun seluruh bagian luar alat kelamin perempuan dan/atau pencederaan atas organ genital perempuan untuk alasan budaya maupun alasan-alasan non-therapeutic lainnya. Biasanya, anak perempuan dikhitan pada usia antara 2 dan 12 tahun (Barstow, 1999). Pada beberapa komunitas, MGP dilakukan ketika anak perempuan masih berusia bayi, sementara pada populasi lain dilakukan menjelang pernikahan atau setelah lahirnya anak pertama.

Mutilasi genitalia perempuan dapat dijumpai diseluruh dunia. Toubia (1994) memperkirakan sedikitnya seratus juta perempuan mengalami MGP. Pelakunya adalah komunitas yang berasal dari berbagai kelas dan kelompok etnik, termasuk Muslim, Kristen, Yahudi, dan penganut agama-agama tradisional Afrika. Asia dan Afrika merupakan benua dengan praktik MGP terbanyak dibandingkan dengan kawasan-kawasan lain. Mesir merupakan negara dengan prevalensi MGP paling tinggi, kendati Mesir pula yang belum lama ini mengeluarkan hukum yang melarang MGP. IRIN (2005) memperkirakan, lebih seratus tiga puluh juta perempuan telah menjadi objek MGP. Setiap tahunnya berlangsung sekitar dua juta prosedur MGP. Berada kisaran yang hampir sama, WHO mengestimasi terdapat seratus hingga seratus empat puluh juta perempuan yang menjalani MGP.

\section{PEMBAHASAN}

\section{MGP di Indonesia}

MGP juga tergolong lazim di Indonesia, khususnya di kawasan pedesaan. UNICEF (2005) mencantumkan Indonesia, bersama dengan Malaysia, sebagai dua negara Asia Tenggara yang banyak mempraktikkan MGP. Hampir seluruh MGP di Indonesia merupakan MGP tipe I dan tipe IV. Kadang, MGP di Indonesia hanya ritual simbolik yang sama sekali tidak mencederai fisik perempuan.

Studi yang dilakukan Rahman (Condro, 2005) di desa Cijeruk menemukan seluruh responden menyunatkan anak perempuannya. Bukan semata fenomena yang sering dianggap sebagai tipikal 'budaya pedalaman', riset di Kemayoran yang tergolong sebagai wilayah perkotaan juga mendapati bahwa 96 persen keluarga di kawasan tersebut mengaku menyunatkan anak perempuan mereka.

Menyikapi maraknya MGP, Kantor Menteri Negara Pemberdayaan Perempuan mendukung semua usaha guna menghentikan praktik khitan pada perempuan di Indonesia. Demikian pula Departemen Kesehatan, seperti dinyatakan Direktur Jenderal Kesehatan Masyarakat melalui surat edarannya (Depkes RI, 2006), semua fasilitas kesehatan pemerintah diminta menyebar-luaskan informasi tentang hal-ihwal khitan pada perempuan. Ini dimaksudkan agar masyarakat memperoleh pemahaman yang lebih komprehensif sebelum memutuskan untuk mengkhitankan anak perempuan mereka, sekaligus sebagai upaya penghapusan kekerasan terhadap perempuan. 
Pembahasan pada seminar yang diselenggarakan Population Council dan Kementerian Negara Pemberdayaan Perempuan pada tahun 2004 menekankan, antara lain, khitan pada perempuan sebagai bentuk pelanggaran hak azasi manusia. Khitan pada perempuan juga diargumentasikan tidak memiliki pertimbangan kesehatan yang kuat yang setara dengan khitan pada laki-laki.

Poin lainnya pada seminar tersebut adalah penekanan tentang pelarangan bagi petugas kesehatan melakukan medikalisasi khitan perempuan. Penelitian yang kedua organisasi itu lakukan pada tahun 2004 di provinsi Sumatera Barat, Jawa Timur, Sulawesi Selatan, Banten, Gorontalo, dan Sulawesi Selatan, menemukan bahwa MGP tidak hanya dipraktikkan oleh dukun bayi maupun juru sunat, tetapi juga oleh petugas kesehatan. Realita ini dinilai meresahkan, karena menjadi indikasi bahwa para tenaga medis terdidik dan professional sekalipun juga mempraktikkan mutilasi genitalia perempuan yang dianggap bertentangan dengan nilai-nilai penghargaan terhadap kaum hawa.

Kendati demikian, pada sisi lain dari realita tersebut, temuan Population Council dan Kementerian Negara Pemberdayaan Perempuan itu menunjukkan adanya perkembangan positif berupa meningkatnya kepercayaan masyarakat pada tenaga kesehatan profesional. Masalahnya, terlepas dari kemungkinan digunakannya pembiusan dan peralatan yang lebih steril, dikritisi bahwa alat khitan yang digunakan oleh petugas kesehatan justru sering lebih tajam, sehingga peluang bagi terjadinya pembuangan jaringan genitalia secara lebih dalam/luas pun menjadi lebih besar. Tren perlibatan tenaga profesional dalam praktik MGP sesungguhnya tidak hanya berlangsung di Indonesia. Selaras dengan itu, the FGC Education and Networking Project (Sarkis, 2003) menguraikan bahwa peningkatan praktik MGP di rumah sakit telah terjadi sejak paroh awal tahun sembilan puluhan.

\section{Alasan Mempraktikkan MGP}

Obaid dalam situs UNICEF (2005) menguraikan lima kategori umum di balik praktik MGP: (1) Pertimbangan kesehatan dan estetika: pada beberapa komunitas, bagian luar alat kelamin perempuan dianggap kotor dan menjijikkan. MGP, berdasarkan pandangan tersebut, dilakukan sebagai bentuk pembersihan terhadap tubuh perempuan, (2)Pertimbangan sosial ekonomi: pada banyak komunitas, kondisi dikhitan adalah syarat bagi perempuan yang akan menikah. Kondisi yang sama acap kali dijadikan syarat bagi perempuan untuk memperoleh warisan. Praktik khitan pada perempuan juga merupakan sumber income bagi praktisi medis, (3) Pertimbangan psikoseksual: unsur mitos melatarbelanagi dilakukannya MGP sebagai alat kontrol atas perempuan, yaitu sebagai jaminan kesucian maupun untuk meningkatkan kepuasan seksual laki-laki, (4) Pertimbangan sosiologis dan budaya: MGP adalah upacara pengabsahan masuknya seorang perempuan ke masa kedewasaan. Sebagai bagian tradisi, praktik MGP menjadi sesuatu yang dijaga kesinambungannya antargenerasi. Adanya mitos bahwa klitoris yang tidak dipotong akan membuat perempuan menjadi budak nafsu dan membesar seperti penis, juga memperkuat alasan sosiokultural di balik praktik MGP, (5) Pertimbangan agama: terdapatnya sejumlah kalangan yang menafsirkan MGP sebagai pelaksanaan ajaran agama, sehingga MGP dijadikan sebagai indikator ketaatan penganut agama (khususnya perempuan) pada keyakinannya.

\section{Tipe MGP}

Organisasi Kesehatan Dunia (WHO) pada tahun 2008 membagi prosedur MGP ke dalam empat tipe. Derajat keparahannya biasanya ditentukan oleh seberapa jauh terjadinya pemotongan/ pengirisan pada jaringan alat kelamin perempuan. MGP Tipe I (Sunna circumcision) didefinisikan WHO, dan dijelaskan juga oleh Sarkis (2003), sebagai pembuangan sebagian maupun keseluruhan klitoris dan/atau tudung klitoris (prepuce). Tipe I selanjutnya dipilah ke dalam tipe Ia dan Ib. Tipe Ia sebatas membuang tudung klitoris, sedangkan tipe Ib membuang tudung klitoris dan klitorisnya sekaligus. 
Penggunaan istilah "Sunna circumcision" mengandung warna kultur tertentu. Pasalnya, kendati diakui bukan sebagai hal yang dipraktikkan secara eksklusif oleh komunitas muslim, namun pemakaian istilah tersebut sebagai sinonim MGP tipe I menunjukkan adanya pandangan umum yang mengidentikkan praktik MGP dengan dunia Islam. MGP Tipe II (excision) dimaknakan sebagai pembuangan sebagian maupun keseluruhan klitoris dan labia minora, baik dengan maupun tanpa pengirisan labia majora. Tipe IIa dilakukan sebatas dengan pembuangan labia minora. Tipe IIb, pembuangan sebagian maupun keseluruhan klitoris dan labia minora. Tipe IIc, pembuangan sebagian maupun keseluruhan klitoris, labia minora, dan labia majora.

MGP Tipe III merupakan prosedur khitan paling ekstrim. Bagian luar organ kelamin perempuan ditiadakan keseluruhannya. MGP Tipe III disebut pula sebagai khitan ala firaun (pharaonic circumcision) atau infibulation. MGP Tipe IV merupakan MGP yang tidak menyertakan pembuangan jaringan. WHO mendefinisikannya sebagai berbagai prosedur lainnya yang ditujukan bukan untuk kepentingan medis.

\section{Efek Psikologis MGP}

Berbeda dengan penelitian tentang efek fisik pada perempuan yang mengalami MGP, jumlah riset tentang efek psikologis MGP ternyata tidak sebanyak yang diduga. Lightfoot-Klein (1993), Walker (1991), serta Walker \&Parmar (1993) menduga, tidak memadainya penelitian tentang efek psikologis yang ditimbulkan MGP merupakan cerminan derajat pemahaman dan kesadaran publik akan kesehatan perempuan. Pandangan tersebut tidak melulu sejajar dengan realita sosial kemasyarakatan yang cenderung masih memosisikan lelaki sebagai jenis kelamin dominan. Dengan kata lain, MGP tidak selalu perwujudan rendahnya penghargaan terhadap jenis kelamin perempuan.

Ambil misal, praktik MGP di daerah pedesaan mengandung nilai sosial yang tinggi. Dengan demikian, MGP dijadikan sebagai sebuah seremoni untuk mendapatkan status sosial di masyarakat. MGP juga dilakukan dalam rangka menyenangkan keluarga serta memenuhi tuntutan teman sebaya. Perempuan dianggap “utuh” setelah menjalani MGP. Masyarakat bisa saja memiliki penalaran seperti tersebut di atas. Persoalannya, banyak perempuan yang mengalami MGP yang kemudian menderita depresi dan kecemasan kronis. Kekhawatiran terbesar muncul berkaitan dengan kondisi fisik alat kelamin, nyeri saat menstruasi (dysmenorrhea), dan ketidak-suburan, setelah menjalani MGP. ...... menyebut, seksualitas perempuan pasca-MGP sangat dipengaruhi oleh tipe MGP yang telah dilakukan serta seberapa jauh si perempuan menginternalisasi tuntutan sosial agar merepresi kebutuhan seksualnya.

Lax (2000) memaparkan beberapa konsekuensi psikologis menyusul MGP, yakni perasaan tidak utuh secara fisik, hilangnya kepercayaan pada pihak lain, depresi, dan guncangan pasca-trauma. Perempuan-perempuan MGP yang kemudian mengalami sindrom penyakit kronis dan kecacatan mobilitas juga dihubungkan dengan trauma dan komplikasi susulan semacam infeksi dan kesulitan menstruasi (Lightfoot-Klein, 1993). Sejumlah kasus gangguan psikopatologi juga dihubungkan langsung dengan MGP, termasuk kesulitan perempuan dalam mengembangkan identitas seksualnya. Efek psikologis lainnya yang dijumpai pada perempuan yang menjalani MGP adalah menurunnya keberfungsian sosial, perasaan tidak berharga, perasaan bersalah, dan munculnya pemikiran untuk bunuh diri.

Menjadikan tipe-tipe MGP sebagai acuan, dapat diasumsikan, gangguan stres pascatrauma akibat MGP cenderung lebih tinggi pada anak-anak perempuan yang menjalani MGP tipe lebih tinggi. Gangguan stres pascatrauma diyakini berhubungan dengan kilas balik (flashback) yang dipicu oleh ingatan akan prosesi MGP yang traumatis, serta diperkuat oleh pengalaman-pengalaman seksual berikutnya, misalnya hubungan seksual, pemeriksaan ginekologis, dan proses melahirkan. 
Tidak terhenti pada sakit fisik dan gangguan psikis, MGP juga memunculkan implikasi sosial bagi para perempuan yang menjalani prosesi tersebut. Beraneka problem susulan setelah menjalani MGP akan mempersempit mobilitas pada perempuan, yang pada gilirannya juga meningkatkan isolasi sosial dan hilangnya keberfungsian diri mereka di tengah-tengah masyarakat. Para perempuan juga berhadapan dengan situasi yang kian kompleks, karena tidak adanya izin dari suami maupun keluarga membuat mereka terlambat atau bahkan sama sekali tidak dapat berkonsultasi dengan profesional medis.

Berdasarkan riset, MGP disimpulkan menjadi penyebab disfungsi seksual. Persetubuhan yang disertai rasa nyeri (dyspareunia), ketidak-mampuan atau penundaan orgasme juga efek yang kerap dijumpai (Brighouse, 1992). El-Defrawi dkk. (2001) mencatat adanya disfungsi seksual yang tinggi (80\%) pada perempuan-perempuan yang di-MGP. Kesulitan seksual tersebut mencakup hilangnya hasrat seksual (45\%), menurunnya sensasi kenikmatan (49\%), dan kegagalan mencapai orgasme $(60,5 \%)$.

Memperkaya temuan di atas, Brighouse (1992) mencatat, masalah-masalah seksual muncul dengan prevalensi yang lebih tinggi (berdasarkan laporan) pada perempuan yang menjalani MGP setelah memasuki usia aktif secara seksual dan setelah melahirkan. Eke \& Nkanginieme (1999) mencatat adanya gangguan kesuburan pasca-MGP pada sejumlah kasus. Ini dapat disebabkan oleh infeksi fisik yang dialami perempuan yang di-MGP. Ketidak-suburan, pada gilirannya, menempatkan perempuan tersebut sebagai perempuan kelas dua.

'Unik’nya, Black \& Debelle (1995) menemukan bahwa pada wilayah-wilayah yang secara kultural menerima praktik MGP, problem psikologis hanya ditemukan dengan skala minimal. Bahkan, bertolak belakang dengan anggapan banyak pihak, masalah-masalah psikologis justru akan dialami oleh perempuan yang tidak menjalani prosedur MGP.

Gambaran nyata yang diperoleh Black dan Debelle tersebut bisa jadi kontroversial, karena seolah memberikan legitimasi bagi pemberlakuan MGP. Dampak psikologis pasca-MGP, menurut mereka, bukan konsekuensi dari pelukaan fisik, melainkan lebih sebagai respon psikologis yang ditentukan oleh positif atau negatifnya persepsi si perempuan dan masyarakat yang mempraktikkan khitan itu sendiri.

Serupa dengan itu adalah deskripsi Rising Daughters Aware (1999) tentang rasa sakit akibat MGP. Lembaga itu menggambarkan, tidak sedikit kalangan yang menafsirkan bahwa pengalaman akan rasa sakit tersebut membuat anak perempuan tersadar akan ikatan persaudaraan sesama mereka. Ini ada kaitannya dengan fakta bahwa MGP kerap kali dilakukan oleh perempuan dewasa yang menjadi kerabat dekat si anak perempuan. Anggapan positif terhadap rasa sakit MGP itu juga terdapat pada para perempuan yang memasuki usia pubertas, yaitu sebagai perwujudan keberhasilan anak memasuki usia dewasa.

Demikian pula, tidak ada bukti yang memadai untuk mendukung klaim bahwa perempuan yang mengalami MGP pasti akan menderita problem seksual dan tidak mampu mencapai orgasme. Disimpulkan, kepuasan seksual perempuan yang mengalami MGP tidak sebatas diakibatkan oleh kerusakan anatomi seksualnya, tetapi juga oleh kemampuannya dalam mengkompensasikan "keterbatasan"nya itu dengan memanfaatkan emosi, fantasi, dan sensori pada bagian tubuh lainnya. Ini terlihat dari sebuah studi yang menemukan bahwa 48\% perempuan yang menjalani MGP tipe I masih dapat merasakan kepuasan seksual bahkan mengalami orgasme. Bahkan 29,8\% perempuan yang diinfibulasi pun masih mengalami sensasi seksual yang sama.

Penjelasannya adalah karena beberapa area sensitif di dasar klitoris, bersama dengan labia minora dan di sekitar lantai vulva, masih ada dan tetap dapat memberikan respon seksual apabila 
distimulasi secara tepat. Juga, bagian-bagian tubuh lainnya dapat menjadi semakin sensitif terhadap rangsangan (hypersensitized) sebagai bentuk kompensasi atas ketiadaan stimulasi pada klitoris.

\section{MGP dan Pandangan Islam ${ }^{1}$}

Berbagai literatur menunjukkan perbedaan pendapat tentang keotentikan hadis-hadis yang membahas ihwal khitan pada perempuan. Perdebatan umumnya berkisar pada hukum khitan pada perempuan (wajib atau sunah) dan prosedur khitan. Munir (2007) menyajikan interpretasinya berdasarkan rangkuman atas kajian referensi yang dilakukannya. Menurut Munir, para cendekiawan muslim pada umumnya sepakat menyebut khitan sebagai sesuatu yang disyariatkan (masyru'), baik bagi laki-laki maupun perempuan.

Mengenai hukumnya, Munir (2007) mengklasifikasi pendapat-pendapat tentang khitan pada perempuan ke dalam tiga arus utama. Pertama, sebagian ulama bermazhab Syafi'i, Hanbali, dan sebagian ulama Maliki mewajibkan khitan bagi jenis kelamin lelaki dan perempuan. Kedua, segolongan ulama dari mazhab Hanafi, Imam Malik, dan Imam Ahmad. Mereka berpandangan khitan sebagai hal yang di-sunah ${ }^{2}$-kan, baik bagi laki-laki maupun perempuan. Ketiga, kewajiban khitan bagi laki-laki dan kemuliaan bagi perempuan (makramah/mustahab), dikemukakan oleh sebagian ulama Maliki, ulama Zhahiry, dan Imam Ahmad.

Terlepas dari itu, berbeda dengan pandangan awam, khitan pada perempuan sesungguhnya tidak berawal dari tradisi Islam. Banyak komunitas yang telah menerapkan khitan pada anak-anak perempuan mereka sejak tempo dulu, jauh sebelum tibanya masa Islam.

\section{Agenda API - Beberapa Pertimbangan Strategis}

UNFPA, sebuah Agensi di bawah Perserikatan Bangsa-bangsa yang menangani masalah kependudukan, bersama UNICEF, pada tahun 2007 menetapkan enam belas bentuk kekerasan terhadap perempuan. Salah satunya adalah mutilasi genitalia perempuan (MGP).

Uni Eropa, melalui kampanye End FGM yang dimulai pada tahun 2010, memiliki sikap sama dengan menyebut mutilasi genitalia perempuan sebagai "pelanggaran kotor terhadap hak azasi para perempuan dewasa dan kanak-kanak" (hal. 2). Ditegaskan, "Praktik mutilasi genitalia perempuan mengesampingkan hak kaum hawa untuk hidup, hak atas integritas fisik dan mental, bebas dari kekerasan, standar kesehatan tertinggi yang memungkinkan, bebas dari diskriminasi berbasis seks, bebas dari penyiksaan, serta bebas dari seluruh perlakuan yang menyiksa, keji, tidak manusiawi, dan merendahkan harkat” (hal. 2).

Menghadapi maraknya MGP di berbagai belahan dunia, termasuk di negara-negara berpenduduk mayoritas muslim seperti Indonesia, anggaran sebesar 44 juta dollar dialokasikan untuk mengurangi praktik MGP hingga 40 persen di 16 negara selambatnya pada tahun 2015. Melalui berbagai inisiatifnya, organisasi-organisasi internasional di bawah PBB berupaya mendorong masyarakat untuk menghentikan MGP. Seluruh aktivitasnya difokuskan untuk melakukan advokasi dan kemitraan bersama pemerintah, kalangan agamawan, penyedia sarana kesehatan reproduksi, media, komunitas sipil, di samping menghasilkan dan menyebar-luaskan informasi perihal normanorma sosial yang berpengaruh negatif bagi kesehatan dan kesejahteraan perempuan dan anak-anak.

\footnotetext{
${ }^{1}$ Baca, antara lain, Ensiklopedi Hukum Islam, editor Abdul Azis Dahlan et al., Jakarta, 1997, Vol 3, sub-bab

"Khitan”

${ }^{2}$ Sunah: jika tidak dilakukan, tidak apa-apa. Jikadilakukan, berganjaran pahala.
} 
Rangkaian program tersebut juga ditujukan untuk memperkuat komitmen dunia sekaligus mengembangkan sebuah kerangka kerja berskala global guna mempercepat langkah-langkah penghentian MGP. Pemberantasan MGP juga selaras dengan sasaran pembangunan milenia (Millenium Development Goals). MDG adalah perwujudan komitmen dunia dalam rangka mencapai delapan sasaran terkait pemberantasan korupsi. Secara spesifik, sasaran ketiga pembangunan milenia, yakni memromosikan kesetaraan gender dan memberdayakan kaum perempuan, memberikan basis yang kuat bagi langkah-langkah pengentian praktik mutilasi genitalia perempuan. Seperti diuraikan di atas, tanpa mengesampingkan kompleksitas yang menaungi MGP, praktik ini pada umumnya dipandang sebagai bentuk penindasan terhadap jenis kelamin perempuan. Itu pula yang eksplisit ditegaskan oleh lembaga semacam UN Commission on Population and Development Resolution on Health, Morbodity, Mortality and Development. Atas dasar itu, kampanye penghentian MGP merupakan salah satu bentuk aksi konkrit guna mencapai sasaran ketiga pembangunan milenia tersebut.

Kombinasi antara program berkesinambungan dan ketersediaan dana dipandang sebagai kunci keberhasilan ditekannya praktik MGP pada banyak negara, termasuk negara-negara yang tergolong belum berkembang, selama lima belas tahun belakangan ini. Di negara-negara tersebut, bersama dengan negara-negara yang telah maju, mencantumkan pengaturan bahkan pelarangan praktik MGP secara khusus pada berbagai legislasi mereka.

Seiring dengan tren positif tersebut, Indonesia perlu mengambil peran lebih signifikan guna meminimalisasi praktik MGP di Tanah Air. Apalagi, sesuai perbincangan penulis dengan staf Komnas Perempuan berinisial " $\mathrm{M}$ ", hingga saat ini belum satu pun produk perundang-undangan Indonesia yang membahas masalah MGP. Upaya perlindungan terhadap hak-hak perempuan di Indonesia baru diatur dalam dua legislasi. Yaitu, UU Kekerasan Dalam Rumah Tangga (UU KDRT) dan Konvensi tentang Penghapusan Segala Bentuk Diskriminasi Terhadap Perempuan.

Mencermati pasal-pasal yang terdapat pada Konvensi tentang Penghapusan Segala Bentuk Diskriminasi Terhadap Perempuan, pasal 5 dan pasal 12 poin $\mathrm{f}$ memang memuat kewajiban bagi adanya langkah konkret guna menanggulangi tindakan kekerasan terhadap perempuan. Pasal 5 konvensi tersebut mewajibkan negara-negara peserta untuk "membuat peraturan-peraturan yang tepat, dalam rangka mengubah pola tingkah laku sosial dan budaya laki-laki dan perempuan dengan maksud untuk mencapai penghapusan prasangka-prasangka, kebiasaan-kebiasaan dan segala praktek lainnya yang berdasarkan atas inferioritas atau superioritas salah satu jenis kelamin atau berdasar peranan stereotip bagi laki-laki dan perempuan”. Demikian pula pasal 12 poin $\mathrm{f}$ yang juga mengharuskan negara-negara peserta untuk menyusun "undang-undang untuk mengubah dan menghapuskan undangundang, peraturan-peraturan, keblasaan-kebiasaan dan praktek-praktek yang diskriminatif terhadap perempuan”. Disayangkan, memerhatikan fakta bahwa di Indonesia praktik MGP masih dipolemikkan pembolehan maupun pelarangannya, maka ke depan dibutuhkan legislasi yang lebih spesifik dan eksplisit menetapkan pengaturan terhadap praktik MGP.

Himpunan Psikologi Indonesia (HIMPSI) selaku organisasi yang memayungi seluruh sarjana psikologi seindonesia sepatutnya menunjukkan kiprah nyata dalam kampanye penghentian MGP di Indonesia. Kontribusi HIMPSI dalam agenda ini dapat dikemas melalui pelayanan kesehatan mental berbasis masyarakat, dan tidak utamanya berfokus pada aktivitas yang bersifat therapeutic. Fokus kegiatannya adalah melakukan sintesa antara kajian psikologi dan kaidah-kaidah kultural (termasuk agama) sebagai materi edukatif guna membangun pemahaman yang lebih jernih kepada publik dan otoritas pengambil keputusan akan konsekuensi-konsekuensi negatif praktik MGP.

Inisiatif yang bersifat edukatif diasumsikan lebih efektif ketimbang sebatas menekan otoritas terkait untuk mengeluarkan legislasi yang melarang MGP. Dasar argumentasinya adalah belajar dari

\footnotetext{
${ }^{3}$ Perbincangan pribadi (23 Desember 2009)
} 
pengalaman negara-negara Afrika dan Timur Tengah. Di kedua kawasan tersebut, meskipun MGP telah diberikan status ilegal, namun legislasi yang disusun tidak berhasil menekan jumlah anak perempuan yang dikenai MGP. Tambahan lagi, sesuai pernyataan Amnesti International dalam rilisnya pada tahun 1996, banyak pemerintahan yang tidak mengambil langkah serius guna menghapus kebiasaan yang "melanggar standar-standar internasional tentang hak azasi manusia". Faktanya, minimnya pengawasan dari pemerintah justru membuat legislasi yang melarang MGP semakin tidak bergigi.

\section{SIMPULAN}

Bertitik tolak dari kenyataan MGP sebagai sebuah isu sensitif, keberadaan HIMPSI untuk turut serta menghentikan MGP pun semakin strategis. Kalangan internasional umumnya berpendapat bahwa, untuk menyukseskan kampanye ini, peran utama perlu diberikan kepada unit-unit lokal. Dengan kata lain, program yang ditujukan untuk menghentikan MGP idealnya tidak dilakukan langsung oleh unit internasional yang sejak awal memang telah memiliki kepedulian pada area ini. Institusi semacam UNFPA bahkan menyebut bahwa keterlibatan langsung unit internasional dalam kegiatan kampanye/edukasi lokal justru akan berakibat kontraproduktif, yakni membuat program ini terlihat seperti "Western plot to breakdown traditional cultural values and practices". Dengan menempatkan mutilasi genitalia perempuan sebagai isu global yang ditangani melalui pendekatan lokal, bagi HIMPSI sendiri, ada beberapa elemen strategis yang bernilai positif. Pertama, HIMPSI dapat berperan efektif dalam konteks penghentian MGP, karena secara hipotetis diyakini lebih mampu memandu diskusi dan berinteraksi dengan masyarakat serta membangun keterampilan mereka (jika dibutuhkan). Kedua, fokus pada kampanye penghentian MGP akan membuka peluang bagi HIMPSI untuk membangun kolaborasi jangka panjang dengan lembaga-lembaga internasional guna memperkokoh eksistensi satu sama lain. Kerjasama jangka panjang adalah kemutlakan. Terlebih lewat program edukasi, sasarannya adalah perubahan perilaku. Karena MGP adalah tradisi yang terhayati secara mendalam oleh masyarakat, kesinambungan adalah elemen kunci tercapainya sasaran agenda penghentian MGP. Dengan bingkai kemitraan internasional, manfaat ketiga adalah HIMPSI dapat mengintensifkan aktivitas riset guna mempertajam agenda penghentian MGP yang lebih kontekstual dengan lingkup nasional. Hasil penelitian menjadi basis bagi disusunnya panduan intervensi berbasis ilmiah (bukan pseudoscience apalagi common sense). Tentu saja, keterlibatan masyarakat perlu dibuka seluas-luasnya bagi penyusunan panduan tersebut.

\section{DAFTAR PUSTAKA}

Barstow, D.G. (1999). Female genital mutilation: the penultimate gender abuse. Child Abuse and Neglect, 23, 501-510.

Black, J.A. \& Debelle, G.D. (1995). Female genital mutilation in Britain. British Medical Journal, 310, 1590-1592.

Brighouse, R. (1992). Ritual female circumcision and its effects on female sexual function. Canadian Journal of Human Sexuality, 1, 3-10.

Condro, A. (2005) Hentikan Medikalisasi Sunat Perempuan. Artikel Kompas, Rabu, 1 Juni 2005.

Depkes RI (2006) Surat Edaran (SE) Dirjen Bina Kesehatan Masyarakat Nomor HK 00.07.1.31047 a tentang Larangan Medikalisasi Sunat Perempuan bagi Petugas Kesehatan. Tertanggal 20 April 2006 
Eke, N. \& Nkanginieme, K.E. (1999). Female genital mutilation: a global bug that should not cross the millennium bridge. World Journal of Surgery, 23, 1082-1086.

Eldefrawi, M.H., Lofty, G., Dandash, K.F., Refaat, A.H. \& Eyada, M. (2001). Female genital mutilation and its psychosexual impact. Journal of Sex and Marital Therapy, 27, 465-473.

IRIN (2005). "Razor's Edge - The Controversy of Female Genital Mutilation". IRIN. Diunduh dari http://www.irinnews.org/IndepthMain.aspx?IndepthId=15\&ReportId=62462. Read more: http://www.answers.com/topic/female-genital-mutilation\#ixzz1DY5dkIYb

Lax, R.F. (2000). Socially sanctioned violence against women: female genital mutilation is its most brutal form. Clinical Social Work Journal, 28, 403-412.

Lightfoot-Klein, H. (1993), Prisoners of Ritual, diterbitkan dengan judul, Das Grausame Ritual, Frankfurt: Fischer Verlag.

Munir, A. A. (2007), Hukum dan hikmah khitan wanita menurut hukum Islam. Diunduh dari http://www.uinsuska.info/syariah/attachments/145_Akmal\%20Munir.pdf

Sarkis, M. (2003). Female Genital Cutting (FGC): An Introduction. Retrieved from http://www.fgmnetwork.org/intro/fgmintro.html.

Surat Edaran Direktur Jenderal Bina Kesehatan Masyarakat Nomor: HK.00.07.1.3.1047a tanggal 20 April 2006 tentang Larangan Medikalisasi Sunat Perempuan bagi Petugas Kesehatan.

Toubia, N., (1994) “Female circumcision as a public health issue” New England Journal of Medicine, 331(13): 712-716.

UNICEF (2005), Female Genital Mutilation/Cutting: A statistical exploration. Diunduh dari http://www.unicef.org/publications/files/FGM-C final_10 October.pdf

Walker, A. (1991) Possessing the Secret of Joy, London: Vintage.

Walker, A. dan Parmar, P. (1993) Warrior Marks: Female Genital Mutilation and the Sexual Blinding of Women. New York: Harcourt Brace. 